\title{
A systematic review of treating recurrent head and neck cancer: a reintroduction of brachytherapy with or without surgery
}

\author{
Julianna Rodin, MD!, Voichita Bar-Ad, MD², David Cognetti, MD', Joseph Curry, MD', Jennifer Johnson, MD, PhD³, \\ Chad Zender, MD4, Laura Doyle, MS², David Kutler, MD5, Benjamin Leiby, PhD6'. William Keane, MD!, Adam Luginbuhl, MD' \\ 'Department of Otolaryngology, Thomas Jefferson University, Philadelphia, PA, ${ }^{2}$ Department of Radiation Oncology, Thomas Jefferson \\ University, Philadel phia, PA, ${ }^{3}$ Department of Otolaryngology, Case Western Reserve University School of Medicine, Cleveland, OH, \\ ${ }^{4}$ Department of Medical Oncology, Thomas Jefferson University, Philadelphia, PA, ${ }^{5}$ Department of Otolaryngology. Weill Cornell Medical \\ Center, New York, NY, 'Department of Biostatistics, Thomas Jefferson University, Philadelphia, PA, USA
}

\begin{abstract}
Purpose: To review brachytherapy use in recurrent head and neck carcinoma (RHNC) with focus on its efficacy and complication rates.

Material and methods: A literature search of PubMed, Ovid, Google Scholar, and Scopus was conducted from 1990 to 2017. Publications describing treatment of RHNC with brachytherapy with or without surgery were included. The focus of this review is on oncologic outcomes and the safety of brachytherapy in the recurrent setting.

Results: Thirty studies involving RHNC treatment with brachytherapy were reviewed. Brachytherapy as adjunctive treatment to surgical resection appears to be associated with an improved local regional control and overall survival, when compared with the published rates for re-irradiation utilizing external beam radiotherapy (RT) or brachytherapy alone. Safety data remains variable with different isotopes and dose rates with implantable brachytherapy demonstrating a tolerable side effect profile.

Conclusions: Although surgery remains a mainstay treatment for RHNC, intraoperative interstitial brachytherapy delivery as adjunctive therapy may improve the treatment outcome and may be associated with fewer complication rates as compared to reirradiation using external beam radiotherapy. Further investigations are required to elucidate the role of brachytherapy for RHNC.

J Contemp Brachytherapy 2018; 10, 5: 454-462 DOI: https://doi.org/10.5114/jcb.2018.79399
\end{abstract}

Key words: cesium, head and neck cancer, recurrent.

\section{Purpose}

Head and neck carcinoma (HNC) continue to be a commonly diagnosed cancer with almost 50,000 new cases and almost 10,000 deaths each year [1]. More than $90 \%$ of HNC are classified as squamous cell carcinoma, and cases have increased by nearly 5,000 new patients over two years [2,3]. Patients with locally advanced disease generally are treated with an algorithm of surgical resection, radiotherapy (RT), and/or chemoradiotherapy with curative intent. Unfortunately, depending on subsite and stage, almost half of these advanced stage patients fail this approach in the first 5 years [4,5]. The predominant pattern of recurrence is in a locoregional manner [5]. Surgical resection for these patients has become the mainstay of treatment in resectable cases, and re-irradiation as the only locoregional treatment modality for unresectable cases.
Brachytherapy with or without salvage surgery has often been used for this group of cancer patients with RHNC. Compared to external beam radiation therapy (EBRT) delivery systems, including intensity modulated radiation therapy (IMRT) and proton beam therapy, brachytherapy offers focused dose delivery and fewer early toxic effects, while minimizing adjacent non-cancer tissue toxicity, specifically in previously irradiated fields [5]. This protection of adjacent normal tissue can result in preservation of laryngeal and tongue function. Although brachytherapy has been utilized for recurrent head and neck cancer (RHNC) for years, its use has been limited due to availability of technical expertise, variable isotope implantation technical issues, and introduction of IMRT and other alternative EBRT modalities. Brachytherapy can be delivered via permanent implants (using low-doserate brachytherapy or LDR or high-dose-rate brachyther-
Address for correspondence: Adam Luginbuhl, MD, Department of Otolaryngology, Thomas Jefferson University, 925 Chestnut Street, 6th floor, Philadelphia, PA 19107 United States, phone: +1 215-503-6828, e-mail: adam.luginbuhl@jefferson.edu
Received: 30.05 .2017

Accepted: 21.10 .2018

Published: 30.10 .2018 
apy or HDR) or via removable catheters through which typically high activity radioisotopes are inserted (using HDR or pulsed-dose-rate brachytherapy or PDR) [6]. Permanent implants may be advantageous in patients with recurrence in irregular surfaces that are not suitable for catheter-based isotope delivery [7]. This review describes brachytherapy efficacy in recurrent primary HNC and recurrence in neck disease, and potential complications of brachytherapy. We separated studies based on whether brachytherapy was the sole treatment or in conjunction with surgical tumor resection.

\section{Material and methods}

A literature search using PubMed, Ovid, Google Scholar, and Scopus was conducted. Databases were searched for the terms 'recurrent head and neck cancer' AND 'brachytherapy' between 1990 and 2017. Additional search terms included 'Cesium-131', 'Iridium-192', and 'Iodine-125'. The general criteria for the studies to be included were publications describing brachytherapy use in recurrent HNC of various sites, with particular focus on treatment outcomes and complications. Publications involving ${ }^{131} \mathrm{Cs}$ brachytherapy are also described. The search identified a total of 380 papers, with 350 papers being excluded after title and abstract screening. In these excluded papers, brachytherapy in recurrent HNC of various sites was not the chief focus. The remaining 30 studies reported adequate information according to the criteria. Statistical analysis was also performed to compare recurrence rates in studies, which used brachytherapy with surgery versus brachytherapy alone.

\section{Results}

In the 30 reviewed studies, $95 \%$ (1,440 of 1,515 patients) had prior radiation therapy, making radiotherapy treatment options limited. In 23 of these studies, brachytherapy was administered using Iridium-192 (192Ir) in 1,003 patients, Iodine-125 ( $\left.{ }^{125} \mathrm{I}\right)$ in 131 patients, and Cesium-131 $\left({ }^{131} \mathrm{Cs}\right)$ in 35 patients. Seven studies did not explicitly state which type of isotope was used $[8,9,10,11,12,13,14]$. Brachytherapy was incorporated into treatment planning with or without salvage surgery in a combined modality approach. Occasionally, brachytherapy was also followed by further radiation therapy or chemotherapy. Reirradiation with brachytherapy was used for local, locoregional, or nodal recurrence or neck disease and not for distant metastatic spread. As with most forms of reirradiation, the toxicity profile of brachytherapy includes neurologic toxicity, dysphagia, carotid artery rupture, skin necrosis, fistulas, and osteoradionecrosis [15,16]. These aspects and other considerations within the studies are described in further detail below.

Table 1. Overview of studies treating recurrent head and neck squamous cell carcinoma using brachytherapy alone

\begin{tabular}{|c|c|c|c|c|c|c|}
\hline Author, Year & $N$ & Brachytherapy & Total dose & Additional therapy & Results & Complications \\
\hline $\begin{array}{l}\text { Grimard, } \\
2006[5]\end{array}$ & 82 & Ir 192; LDR & $\geq 55 \mathrm{~Gy}$ & $\begin{array}{c}\text { Surgery (14), } \\
\text { EBRT (3), } \\
\text { Surgery + EBRT (6) }\end{array}$ & $\begin{array}{l}\text { LC at } 2 \text { years: } 37 \% \\
\text { OS at } 2 \text { years: } 33 \%\end{array}$ & $\begin{array}{l}8.5 \% \text { acute toxicity } \\
22 \% \text { late toxicity }\end{array}$ \\
\hline $\begin{array}{l}\text { Strnad, } \\
2014 \text { [8] }\end{array}$ & 104 & PDR & $\begin{array}{l}55 \text { Gy or } 24 \text { Gy } \\
\text { (when +EBRT) }\end{array}$ & $\begin{array}{l}\text { Surgery }(51 \%), \\
\text { EBRT }(32 \%), \\
\text { Chemo }(56 \%)\end{array}$ & $\begin{array}{l}\text { LC at } 5 \text { years: } 82 \% \\
\text { OS at } 5 \text { years: } 21 \%\end{array}$ & $31 \%$ late toxicity \\
\hline $\begin{array}{l}\text { Strnad, } \\
2014[12]\end{array}$ & 51 & PDR & $\begin{array}{l}60 \text { Gy or } 27 \text { Gy } \\
\text { (when +EBRT) }\end{array}$ & $\begin{array}{l}\text { EBRT }(22 \%), \\
\text { Chemo }(69 \%)\end{array}$ & LC at 5 years: $57 \%$ & $\begin{array}{l}10 \% \text { acute grade } 3 \\
29 \% \text { late toxicity }\end{array}$ \\
\hline $\begin{array}{l}\text { Puthawala, } \\
2001 \text { [17] }\end{array}$ & 220 & Ir 192; LDR & Median: 53 Gy & Chemo (88) & $\begin{array}{l}\text { LC at } 5 \text { years: } 51 \% \\
\text { OS at } 5 \text { years: } 20 \%\end{array}$ & $\begin{array}{c}60 \% \text { acute toxicity } \\
27 \% \text { late toxicity } \\
\text { (65\% of which had RT } \\
>65 \text { Gy) }\end{array}$ \\
\hline $\begin{array}{l}\text { Hepel, } \\
2005 \text { [18] }\end{array}$ & 30 & Ir 192; HDR & Mean: 34 Gy & $\begin{array}{c}\text { Chemo }(43 \%), \\
\text { EBRT }(6 \%)\end{array}$ & $\begin{array}{l}\text { LC at } 2 \text { years: } 67 \% \\
\text { OS at } 2 \text { years: } 37 \%\end{array}$ & $\begin{array}{c}16 \% \text { late grade } 3-4 \\
\text { toxicity }\end{array}$ \\
\hline $\begin{array}{l}\text { Jiang, } \\
2011[19]\end{array}$ & 29 & $\begin{array}{l}\text { I 125; LDR, } \\
\text { US-guided }\end{array}$ & Median: $D_{90} 130$ Gy & Not mentioned & $\begin{array}{l}\text { LC at } 2 \text { years: } 35 \% \\
\text { OS at } 2 \text { years: } 28 \%\end{array}$ & $\begin{array}{c}\text { No carotid rupture } \\
\text { or soft tissue/bone } \\
\text { necrosis }\end{array}$ \\
\hline $\begin{array}{l}\text { Glatzel, } \\
2002 \text { [37] }\end{array}$ & 90 & Ir 192; HDR & Median: 17.5 Gy & Not mentioned & Median: OS 6 Mo & $7 \%$ late grade $3-4$ \\
\hline $\begin{array}{l}\text { Zhu, } \\
2013 \text { [32] }\end{array}$ & 19 & $\begin{array}{l}\text { I 125; LDR, } \\
\text { US or CT-guided }\end{array}$ & Median: $D_{90} 131 \mathrm{~Gy}$ & Not mentioned & $\begin{array}{l}\text { LC at } 2 \text { years: } 27.5 \% \\
\text { OS at } 2 \text { years: } 18 \%\end{array}$ & $\begin{array}{l}\text { No grade } 4 \text { or } \\
5 \text { toxicity }\end{array}$ \\
\hline $\begin{array}{l}\text { Meng, } \\
2012[38]\end{array}$ & 17 & $\begin{array}{l}\text { I 125; LDR, } \\
\text { US or CT-guided }\end{array}$ & Median: $D_{90} 126$ Gy & Not mentioned & $\begin{array}{l}\text { LC at } 2 \text { years: } 50 \% \\
\text { OS at } 2 \text { years: } 24 \%\end{array}$ & $\begin{array}{c}\text { No grade } 3 \text { or } \\
4 \text { toxicity }\end{array}$ \\
\hline $\begin{array}{l}\text { Wiegand, } \\
2013 \text { [39] }\end{array}$ & 12 & Ir 192; HDR & Mean: 20-33 Gy & Not mentioned & Median: OS 8.5 Mo & $\begin{array}{l}\text { No serious complica- } \\
\text { tions }\end{array}$ \\
\hline
\end{tabular}

Ir 192 - Iridium 192; I 125 - lodine 125; Gy-Gray; LDR-low-dose-rate; HDR-high-dose-rate; PDR-pulsed-dose-rate; US - ultrasound; CT - computed tomography; $E B R T$ - external beam radiation therapy; $R T$ - radiotherapy; $L C$ - local control; OS - overall survival 


\section{Brachytherapy for local disease: with and without salvage surgery}

Re-irradiation with brachytherapy has been used as an option for resectable and unresectable RHNC cases. While salvage surgery in general is favored, its use may be limited by the extent of disease and the cancer's intimate anatomic relationship to adjacent structures. Lowdose-rate (LDR), high-dose-rate (HDR), and pulsed-doserate (PDR) brachytherapy can be used as monotherapy alone or adjuvantly with salvage surgery. Tables 1 and 2 provide details of all studies using brachytherapy alone and with surgery, respectively. Some of these studies are further described below.

The use of brachytherapy alone was associated with lower local control (LC) and overall survival (OS) rates. In a study by Puthawala et al. [17], 220 patients with RHNC received salvage brachytherapy using LDR interstitial Iridium-192 ( ${ }^{192} \mathrm{Ir}$ ) implants. They achieved 2-, 5-, and 10 -year disease-free survival (DFS) rates of $60 \%, 33 \%$, and $22 \%$, respectively [17]. Hepel et al. [18] found similar results using HDR ${ }^{192}$ Ir brachytherapy with DFS at 2 years being $45 \%$ and OS at 1 and 2 years, $56 \%$ and $37 \%$, respectively. Strnad et al. [8] found that their LC rates at 2, 5, and 10 years were $92.5 \%, 82.4 \%$, and $58.9 \%$, respectively, with a 5 -year OS of $21 \%$ using PDR brachytherapy. Jiang et al. [19] used LDR ${ }^{125}$ I ultrasound-guided permanent seeds in patients with RHNC ineligible for salvage surgery, and achieved LC rates at 1,2 , and 3 years of $53.1 \%, 34.8 \%$, and $17.4 \%$, and OS rates at 1,2 , and 3 years of $54.1 \%, 27.5 \%$, and $27.5 \%$, respectively.

In the recurrent setting, surgical resection remains the foundation of treatment for resectable disease, when looking at oncologic outcomes. In a study by Grimard et al. [5], brachytherapy was used as monotherapy in 22 of 45 patients and with surgery in 20 of 45 patients [5]. While not statistically significant, salvage surgery with adjuvant brachytherapy led to better locoregional control [5]. Narayana et al. [9] studied patients with recurrent HNC with 18/30 receiving surgery and $\mathrm{HDR}, 3 / 30$ receiving EBRT and HDR, and 9/30 receiving HDR alone. There was improved local control in patients who received salvage surgery versus those without surgery: $88 \%$ vs. $40 \%$ [9]. In a study by Rudzianskas et al. [20], 43\% of patients

Table 2. Overview of studies treating recurrent head and neck squamous cell carcinoma using surgery with brachytherapy

\begin{tabular}{|c|c|c|c|c|c|c|}
\hline Author, year & $N$ & Brachytherapy & Total dose & $\begin{array}{l}\text { Surgical } \\
\text { resection }\end{array}$ & Results & Complications \\
\hline $\begin{array}{l}\text { Henderson, } \\
2016[6]\end{array}$ & 23 & $\begin{array}{l}\text { Ir 192; HDR } \\
\text { Cs-131; LDR }\end{array}$ & $\begin{array}{l}\text { Mean: } 21 \text { Gy } \\
\text { Mean: } 81 \text { Gy }\end{array}$ & Yes & Not mentioned & $\begin{array}{l}50 \% \text { toxicity in HDR pts } \\
30 \% \text { toxicity in LDR pts }\end{array}$ \\
\hline $\begin{array}{l}\text { Narayana, } \\
2007[9]\end{array}$ & 30 & $\mathrm{HDR}$ & $\begin{array}{c}34 \text { Gy (+ surgery) } \\
20 \text { Gy (+ EBRT) } \\
40 \text { Gy (only BT) }\end{array}$ & $\begin{array}{l}60 \% \text { Yes } \\
40 \% \text { No }\end{array}$ & $\begin{array}{l}\text { LC at } 2 \text { years: } 71 \% \\
(88 \%+\text { surgery, } \\
40 \% \text { - surgery) } \\
\text { OS at } 2 \text { years: } 63 \%\end{array}$ & $33 \%$ grade $2-3$ toxicity \\
\hline $\begin{array}{l}\text { Martinez- } \\
\text { Fernandez, } \\
2017[10]\end{array}$ & 63 & HDR & Total: 32 or 40 Gy & Yes & $\begin{array}{l}\text { LC at } 15 \text { years: } 41 \% \\
\text { OS at } 15 \text { years: } 12 \%\end{array}$ & $51 \%$ grade $\geq 3$ toxicity \\
\hline $\begin{array}{l}\text { Schiefke, } \\
2008[11]\end{array}$ & 13 & $\mathrm{HDR}$ & Median: 30 Gy & Yes & $\begin{array}{l}\text { OS at } 2 \text { years: } 65 \% \\
\text { LR failure in } 38 \%\end{array}$ & $\begin{array}{l}69 \% \text { acute toxicity } \\
31 \% \text { late toxicity }\end{array}$ \\
\hline $\begin{array}{l}\text { Scala, } \\
2013[13]\end{array}$ & 76 & HDR & Median rate: 1,200 cGy & Yes & $\begin{array}{l}\text { LC at } 2 \text { years: } 62 \% \\
\text { OS at } 2 \text { years: } 42 \%\end{array}$ & No grade 3-4 toxicity \\
\hline $\begin{array}{l}\text { Rudzianskas, } \\
2012[20]\end{array}$ & 30 & Ir 192; HDR & Total: $30 \mathrm{~Gy}$ & $\begin{array}{l}43 \% \text { Yes } \\
57 \% \text { No }\end{array}$ & $\begin{array}{l}\text { LC at } 2 \text { years: } 77 \% \\
\text { OS at } 2 \text { years: } 62 \% \\
\text { Non-surgical group: } \\
\text { LC at } 2 \text { years: } 47 \% \\
\text { OS at } 2 \text { years: } 35 \%\end{array}$ & $\begin{array}{l}10 \% \text { acute grade } 2-3 \\
10 \% \text { late grade } 2-4\end{array}$ \\
\hline $\begin{array}{l}\text { Park, } \\
1991[21]\end{array}$ & 35 & I 125; LDR & $\begin{array}{l}\text { Mean rate: } \\
8,280 \text { cGy }\end{array}$ & Yes & $\begin{array}{l}\text { OS at } 2 \text { years: } 38 \% \\
\text { OS at } 5 \text { years: } 29 \%\end{array}$ & $\begin{array}{c}36 \% \text { acute and/or late } \\
\text { toxicity }\end{array}$ \\
\hline $\begin{array}{l}\text { Pellizzon, } \\
2005 \text { [22] }\end{array}$ & 42 & Ir 192; HDR & Median: 24 Gy & Yes & $\begin{array}{c}\text { Crude LC } 57 \% \\
\text { OS at } 5 \text { years: } 52.5 \%\end{array}$ & $\begin{array}{c}19 \% \text { acute and/or late } \\
\text { toxicity }\end{array}$ \\
\hline $\begin{array}{l}\text { Pham, } \\
2015 \text { [23] }\end{array}$ & 18 & Cs 131; LDR & Median: 80 Gy & Yes & $\begin{array}{l}\text { OS at } 18 \text { mos: } 45 \% \\
\text { LR failure in } 33 \%\end{array}$ & $11 \%$ grade 3 toxicity \\
\hline $\begin{array}{l}\text { Teckie, } \\
2013[41]\end{array}$ & 57 & Ir 192; HDR & Median: 15 Gy & Yes & $\begin{array}{l}\text { OS at } 3 \text { years: } 32 \% \\
\text { LR failure in } 46 \%\end{array}$ & $\begin{array}{l}37 \% \text { grade } 3 \\
\text { No grade } 4-5 \text { toxicity }\end{array}$ \\
\hline $\begin{array}{l}\text { Perry, } \\
2010 \text { [42] }\end{array}$ & 34 & Ir 192; HDR & Median: 15 Gy & Yes & OS at 2 years: $55 \%$ & $29 \%$ grade $3-4$ toxicity \\
\hline
\end{tabular}

Ir 192 - Iridium 192; I 125 - lodine 125; CS 131 - Cesium 131; Gy - Gray; LDR - low-dose-rate; HDR - high-dose-rate; EBRT - external beam radiation therapy; $B T$ - brachytherapy; $L C$ - local control; $L R$ - locoregional; OS - overall survival 
had surgery and HDR with ${ }^{192} \mathrm{Ir}$, while $57 \%$ had HDR alone. Patients who received surgery and brachytherapy had improved 2-year local control rates (77\%) and OS rates $(62 \%)$ versus those with brachytherapy alone $(47 \%$, $35 \%$, respectively) [20]. These differences in locoregional control underscore the overall benefit of surgical resection in the recurrent setting.

In a study by Park et al. [21], LDR ${ }^{125}$ I seeds were implanted in patients with RHNC who all underwent salvage surgery. DFS at 1,2 , and 5 years was $64 \%, 47 \%$, and $41 \%$, respectively, with a 5 -year no evidence of disease (NED) in patients (29\%) [21]. Pellizzon et al. [22] studied patients with RHNC treated with surgery and HDR ${ }^{192}$ Ir brachytherapy with or without further EBRT and found the OS at 5 and 8 years to be $52.5 \%$ and $48.1 \%$. Martinez-Fernandez et al. [10] followed previously irradiated RHNC patients treated with salvage surgery and perioperative HDR brachytherapy for 15 years, finding a 15-year LRC rate of $41.2 \%$ and 15 -year OS rate of $11.6 \%$. Pham et al. [23] showed that in selected patients, ${ }^{131}$ Cs intraoperative seeds with salvage surgery achieved 1-, 2and 3-year LC rates of $69 \%, 62 \%$, and $52 \%$, respectively.

Looking to historic data of re-irradiation using the standard or hyperfractionated IMRT combined with systemic chemotherapy has demonstrated a 2-year survival of $10-25 \%[24,25]$. The previously discussed studies using surgery plus brachytherapy reported a 5 -year overall survival of $33-67 \%$, showing encouraging progress over EBRT plus chemotherapy.

We performed a statistical analysis of the studies to evaluate locoregional recurrence in RHNC patients receiving brachytherapy and surgery vs. brachytherapy alone. Logistic regression was used to compare recurrence rates, and generalized estimating equations (GEE) methods were used to account for clustering within the study. In studies where recurrence rates were not explicitly stated, recurrence rates were extrapolated based on the local and locoregional control rates. For the primary analysis, the rate of locoregional recurrence was $38.8 \%$ $(143 / 369)$ in the surgery with brachytherapy group and $49.0 \%(329 / 671)$ in the brachytherapy alone group. The estimated odds ratio was 0.66 (95\% CI: 0.38-1.12; $p=0.13$ ).

\section{Brachytherapy for nodal disease}

Many studies also have demonstrated brachytherapy use in RHNC with regional failure in the cervical lymph nodes. Table 3 portrays the details of these studies. In the study by Bartochowska et al. [26], patients with unresectable isolated cervical lymph node recurrence had PDR or HDR with ${ }^{192}$ Ir via catheters. Local control rates at 1 and 2 years were $31.7 \%$ and $19 \%$ [26]. Huang et al. [27] achieved better results in 31 patients with RHNC with neck metastases unmanageable with other techniques, achieving LC rates of $64.5 \%$ and $45.1 \%$ at 1 and 2 years. In 74 patients with inoperable recurrent lymphadenopathy, Tselis et al. [28] showed OS rates of $42 \%, 19 \%$, and $6 \%$ at 1,2 , and 3 years, respectively.

In the study by Teudt et al. [14], patients with RHNC underwent revision surgery and perioperative HDR for their recurrent neck metastases. These patients were found to have $78 \%$ and $67 \%$ OS at 2 and 5 years, respectively, with a median survival of 65 months [14]. Nutting et al. [29] also looked at patients with recurrent neck disease undergoing LDR brachytherapy alone, with resection, or with resection and flap surgery. Locoregional control at 2 years in those who had brachytherapy alone was $0 \%$, while those who also had a surgery with or without a flap had improved LRC, $37 \%$ or $33 \%$, respectively [29]. For the neck disease statistical analysis, the rate of locoregional recurrence was $30.9 \%(42 / 136)$ in the surgery with brachytherapy group and $49.0 \%(149 / 304)$ in the brachytherapy alone group. The estimated odds ratio was 0.46 (95\% CI: 0.25-0.86; $p=0.015)$.

\section{Complications}

Due to the nature of the radioactive isotopes, brachytherapy is associated with various radiation exposure concerns. However, these radiation effects appear to be improved in terms of functional organ preservation and reduced irradiation to surrounding normal tissues compared to EBRT or IMRT (Quon). Toxicity is commonly monitored using the Radiation Toxicity Oncology Group (RTOG) common toxicity criteria [30]. Radiation safety procedures, including the use of lead shields and gloves, may be appropriate when handling specific radioisotope implants, which is based on a number of factors including isotope, total source activity, and implant location [31]. The recommended limit of radiation exposure to staff personnel based on federal regulation is $50 \mathrm{mSv} /$ year for "stochastic effects", e.g., cancer or genetic effects, defined as "ones in which the probability of occurrence increases with increasing absorbed dose, but the severity does not depend on the magnitude of the absorbed dose" [31]. In some cases associated with specific radioisotopes, patients were isolated in order to reduce personnel and family radiation exposure, and were required to stay in the hospital longer.

Toxicity complications related to brachytherapy have been explored in various studies using ${ }^{192} \mathrm{Ir}$ and ${ }^{125} \mathrm{I}$ and usually involve necrosis, dysphagia, or fistulas. Tables 1-3 include toxicity rates for studies reviewed. In a review by Kasperts et al. [15], 17\% (120/704) of patients developed soft tissue necrosis and $2 \%(15 / 704)$ developed orocutaneous fistulas. Another 2\% of patients suffered from hemorrhage or carotid blowouts and another 3\% developed osteoradionecrosis [15]. In the study by Grimard et al. [5], acute toxicity occurred in $15.6 \%$ of patients and late toxicity in $40 \%$, with 4 patients developing grade 2 or 3 radionecrosis and 7 patients experiencing dysphagia. In Zhu et al.'s study [32], only one patient had a grade 1 skin reaction, with no patients suffering from soft tissue necrosis or other complications. Henderson et al. [6] looked at patients who underwent HDR or LDR brachytherapy and neck dissection with or without flap coverage. There were complications in $50 \%$ of HDR patients and $29.4 \%$ of LDR patients, with only 3 of 22 patients receiving flaps having complications (2 HDR, 1 LDR) [6]. Martinez-Fernandez et al. [10] found RTOG grade 3 or greater toxicities in $50.8 \%$ of patients, with 17 cases needing further operations due to fistula (6), wound dehiscence (4), bleeding (3), 
Table 3. Overview of studies treating recurrent squamous cell carcinoma as neck disease

\begin{tabular}{|c|c|c|c|c|c|c|}
\hline Author, year & $N$ & Brachytherapy & Total dose & $\begin{array}{l}\text { Surgical } \\
\text { resection }\end{array}$ & Results & Complications \\
\hline $\begin{array}{l}\text { Bartochowska, } \\
2015 \text { [26] }\end{array}$ & 60 & $\begin{array}{c}\text { Ir 192; } \\
\text { PDR (49 pts) or } \\
\text { HDR (11 pts) }\end{array}$ & Median: 20 Gy or 24 Gy & No & $\begin{array}{l}\text { LC at } 2 \text { years: } 27 \% \\
\text { OS at } 2 \text { years: } 19 \%\end{array}$ & $\begin{array}{l}33 \% \text { acute toxicity } \\
12 \% \text { late toxicity }\end{array}$ \\
\hline $\begin{array}{l}\text { Huang, } \\
2016[27]\end{array}$ & 31 & $\begin{array}{l}\text { I 125; LDR, } \\
\text { CT-guided }\end{array}$ & Mean: $D_{90} 101 \mathrm{~Gy}$ & No & $\begin{array}{l}\text { LC at } 2 \text { years: } 45 \% \\
\text { OS at } 2 \text { years: } 45 \%\end{array}$ & No grade 3 or 4 toxicity \\
\hline $\begin{array}{l}\text { Tselis, } \\
2011[28]\end{array}$ & 74 & $\begin{array}{c}\text { Ir 192; } \\
\text { HDR, CT-guided }\end{array}$ & Median: 30 Gy & No & $\begin{array}{l}\text { LC at } 2 \text { years: } 67 \% \\
\text { OS at } 2 \text { years: } 19 \%\end{array}$ & $\begin{array}{l}5 \% \text { acute grade } 3-4 \text { toxicity } \\
8 \% \text { late grade } 3-4 \text { toxicity }\end{array}$ \\
\hline $\begin{array}{l}\text { Kolotas, } \\
2007[43]\end{array}$ & 49 & $\begin{array}{c}\text { Ir 192; } \\
\text { HDR, CT-guided }\end{array}$ & Total: 30 Gy or 36 Gy & No & $\begin{array}{l}\text { LC at } 19 \text { mos: } 69 \% \\
\text { OS at } 2 \text { years: } 31 \% \\
\text { OS at } 3 \text { years: } 6 \%\end{array}$ & $16 \%$ acute grade $2-3$ toxicity \\
\hline $\begin{array}{l}\text { Bollet, } \\
2001[44]\end{array}$ & 84 & Ir 192; LDR & Mean: 56.5 Gy & No & $\begin{array}{l}\text { LC at } 2 \text { years: } 31 \% \\
\text { LC at } 5 \text { years: } 0 \% \\
\text { OS at } 2 \text { years: } 13 \% \\
\text { OS at } 5 \text { years: } 1 \%\end{array}$ & $\begin{array}{l}35 \% \text { grade } 3-4 \text { toxicity } \\
7 \% \text { grade } 5 \text { (death) }\end{array}$ \\
\hline \multicolumn{7}{|c|}{ Brachytherapy combined with surgical resection } \\
\hline $\begin{array}{l}\text { Teudt, } \\
2016[14]\end{array}$ & 9 & HDR & Mean: 27 Gy & Yes & $\begin{array}{l}\text { OS at } 2 \text { years: } 78 \% \\
\text { OS at } 5 \text { years: } 67 \%\end{array}$ & No grade 3 or 4 toxicity \\
\hline $\begin{array}{l}\text { Kupferman, } \\
2007[24]\end{array}$ & 22 & Ir 192; LDR & Median: 60 Gy & Yes & $\begin{array}{l}\text { RC at } 2 \text { years: } 67 \% \\
\text { OS at } 5 \text { years: } 46 \%\end{array}$ & $\begin{array}{c}14 \% \text { acute grade } 3-4 \text { toxicity } \\
18 \% \text { late grade } 3-4 \text { toxicity }\end{array}$ \\
\hline $\begin{array}{l}\text { Nutting, } \\
2006[29]\end{array}$ & 72 & Ir 192; LDR & Total: 60 Gy & $\begin{array}{l}\text { Yes in } 66 \\
\text { No in } 6\end{array}$ & $\begin{array}{l}\text { LC at } 5 \text { years: } 23 \% \\
\text { OS at } 5 \text { years: } 23 \% \\
\text { Non-surgical group: } \\
\text { LC at } 2 \text { years: } 0 \% \\
\text { OS at } 2 \text { years: } 0 \%\end{array}$ & $15 \%$ grade $3-4$ toxicity \\
\hline $\begin{array}{l}\text { Cornes, } \\
1996[40]\end{array}$ & 39 & Ir 192; LDR & Mean: 49.6 Gy & Yes & $\begin{array}{l}\text { LC at } 1 \text { yr: } 63 \% \\
\text { OS at } 2 \text { yrs: } 38 \%\end{array}$ & $\begin{array}{l}5 \% \text { acute grade } 3-4 \text { toxicity } \\
23 \% \text { late grade } 3-4 \text { toxicity }\end{array}$ \\
\hline
\end{tabular}

Ir 192 -Iridium 192; I 125 -lodine 125; Gy-Gray; LDR-low-dose-rate; HDR-high-dose-rate; PDR-pulsed-dose-rate; CT-computed tomography; LC-local control; $R C$ - regional control; OS - overall survival

or other (4). Notably, many forms of brachytherapy did not use permanent implantable seeds but temporary catheters for the purpose of low-dose or high-dose-rate brachytherapy. Hemorrhage after catheter or tube removal was reported [15].

In contrast, Pham et al. [23] reported similar or lower rates of acute and chronic toxicity with ${ }^{131} \mathrm{Cs}$ as compared to studies using ${ }^{192} \mathrm{Ir}$ and ${ }^{125} \mathrm{I}$. Only 2 of 18 patients had grade 3 toxicity and none had grade $4-5$ toxicity. When present, grade 1-2 complications were primarily dermatitis and hoarseness [23]. The risk to healthcare personnel and close family members has been minimized with isotopes like ${ }^{131} \mathrm{Cs}$ compared to some previous brachytherapy isotopes, which required special precautions [31]. Many prior studies portrayed the effects of ${ }^{125} \mathrm{I}$ and ${ }^{192} \mathrm{Ir}$ brachytherapy on RHNC, but fewer studies have explored the use of permanent ${ }^{131} \mathrm{Cs} .{ }^{131} \mathrm{Cs}$ offers a highdose-rate, focused delivery, and less radiation exposure to adjacent tissues, personnel, and the patient's family [23,31]. Compared to ${ }^{125} \mathrm{I},{ }^{131} \mathrm{Cs}$ has a dose-rate several times higher because of its similar energy but much lower half-life (9.69 days) [33]. This allows for ${ }^{131}$ Cs to deliver $\sim 90 \%$ of its dose in a 33-day period, unlike $32 \%$ of the dose delivered by ${ }^{125} \mathrm{I}$ in that time frame [33]. This longer period of time exposes staff and family to potentially in- creased radiation doses and may require special precautions. Suture strands containing ${ }^{131} \mathrm{Cs}$ seeds can be fixed $0.5-1 \mathrm{~cm}$ apart within the tumor bed or come in a pre-imbedded mesh (Figure 1) [31]. With brachytherapy done during salvage surgery, flaps also may help to prevent seed migration and dosimetry alterations. After implantation, seed placement can be monitored radiographically by generating a post-implant plan and toxicity monitored using RTOG common toxicity criteria [30]. In a study by Parasher et al. [31], 28 patients received a median number of twenty ${ }^{131} \mathrm{Cs}$ seeds implanted at $0.5-1 \mathrm{~cm}$ distance for lung or HN cancer, with a median seed activity of $2.4 \mathrm{U}$. Median radiation exposure rate at the skin and at 1 meter was $0.43 \mathrm{mSV}$ and $0.002 \mathrm{mSv}$, respectively. Minimum measurable radiation dose for OSL badge and TLD ring was 1 mrem and 30 mrem [31]. These minimal dose levels allow for patients to interact with family members and caregivers without special precautions like special lead protective equipment or isolation.

\section{Discussion}

Treatment options for RHNC remain limited. Many patients have undergone previous surgeries with or without radiation, chemotherapy, immunotherapies, 

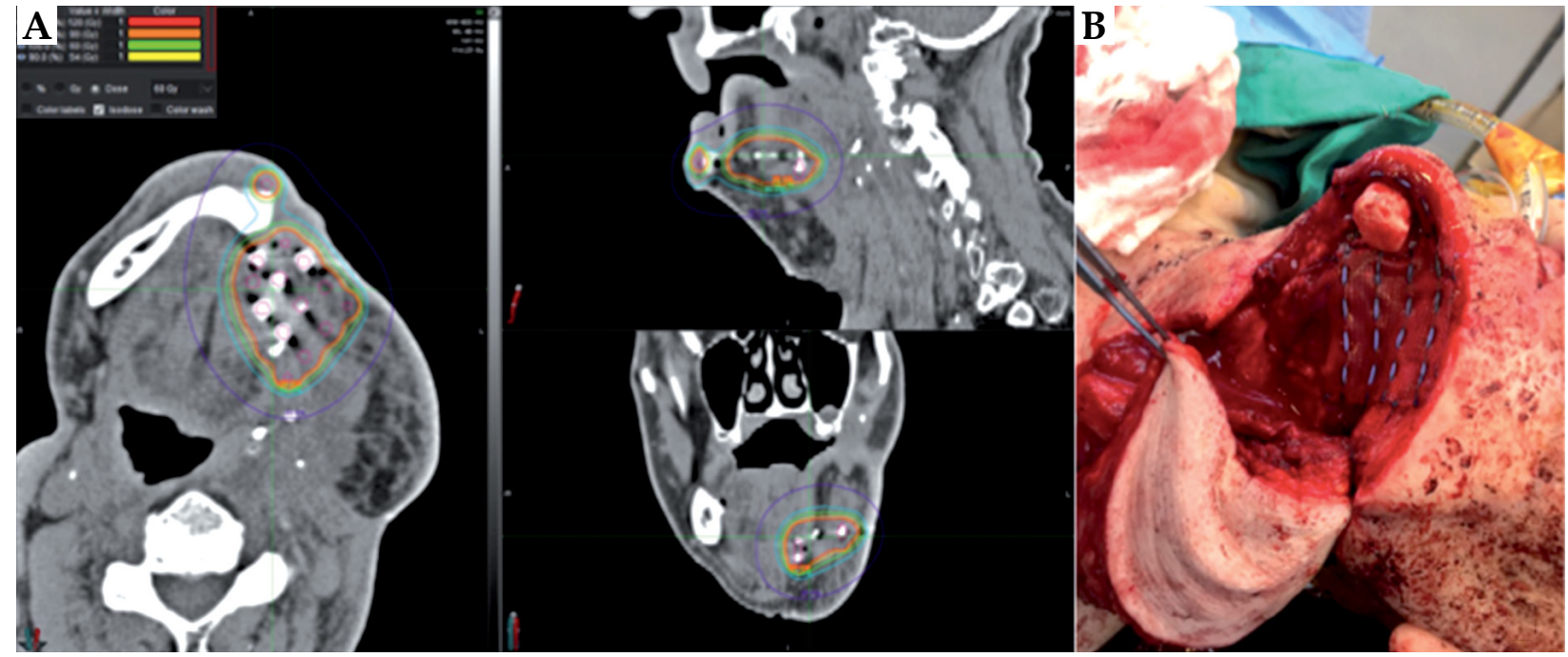

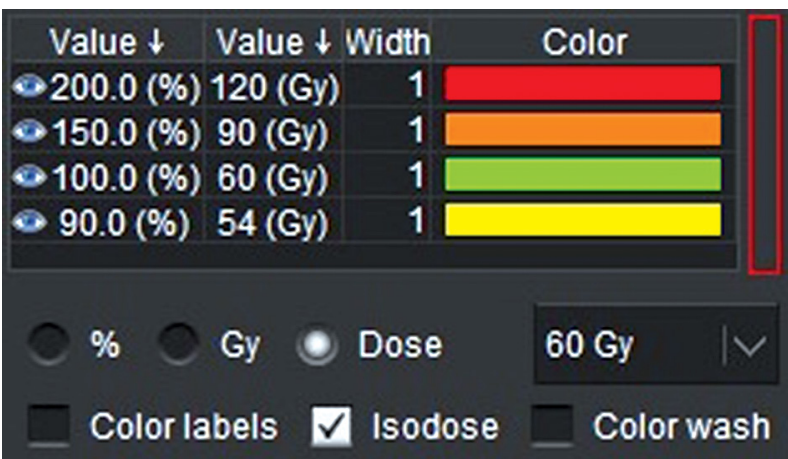

and/or combination therapies, which limit retreatment options with radiation in general and EBRT in particular. The most common current treatment for curative intent is salvage surgery but may not be feasible for all cases $[34,35,36]$. Despite wide margins and G0 resection, locoregional recurrence still thwarts the curative efforts in the recurrent setting. Adding focused radiation directed at the resection margin during salvage surgery, while sparing toxicity to surrounding tissue, is in theory promising.

Brachytherapy has shown to be an effective treatment option with acceptable toxicity profiles for RHNC. When using brachytherapy alone, the reported LR control rates and OS rates at 2 years range from $27.5-92.5 \%$ and $18.2-$ $43 \%$, respectively $[5,8,12,17,18,19,32,37,38,39]$. Some studies have revealed brachytherapy to have enhanced and improved results when combined with salvage surgery $[9,20,29,40]$. Salvage surgery with brachytherapy as adjunctive therapy has 2-year LR control rates and OS rates ranging from $62-88 \%$ and $38-65.3 \%$, respectively $[6,9,10,11$, $13,20,21,22,23,41,42]$. Studies by Narayana et al. and Rudzianskas et al. even compared LC and OS rates at 2 years between those who received brachytherapy with and without surgery and found improved rates in those also receiving surgery $[9,20]$. Although our analysis comparing locoregional recurrence rates of patients receiving surgery with brachytherapy vs. brachytherapy alone was not statistically significant, there was a trend of $38.8 \%$ vs. $49.0 \%$. For brachytherapy use in patients with neck disease, LC
Fig. 1. A) Post-operative radiographic Cesium-131 seed dosimetry. B) Cesium-131 seed placement intra-operatively

and OS rates at 2 years had likewise fair responses, with rates ranging from $27.3-67 \%$ and $13-78 \%$, respectively $[14,24,26,27,28,29,40,43,44]$. Many of these studies had recurrent $\mathrm{HNC}$ with neck metastases that appeared inoperable or unmanageable with other therapies. Yet, analysis in these neck disease patients did show a statistically significant difference $(p=0.015)$ in locoregional recurrence rates $(30.9 \%$ vs. $49.0 \%)$ between the combined treatment group and brachytherapy alone group, respectively.

In comparison, a review by Goodwin [34] described outcomes using salvage surgery alone, the most common salvage treatment. The weighted average of OS at 3 years was $37 \%$ (range: $28-80 \%$ ) and at 5 years was $36.4 \%$ (range: $23-55 \%$ ) [34]. Goodwin [34] also reported the weighted average of disease-free survival (DFS) rates at 2 years: $36.3 \%$ (range: $0-59 \%$ ). Moreover, a literature review by Strojan et al. [35] examined local control and survival rates using conventional EBRT techniques and newer EBRT techniques like IMRT, with or without surgery, in recurrent $\mathrm{HNC}$. Locoregional control rates and OS rates at 2 years using conventional radiation techniques with salvage surgery ranged from 13-74\% (average: 38\%) and $21-67 \%$ (average: $42.5 \%$ ), respectively [35]. Newer RT techniques like IMRT have been showing better outcomes. For example, a study by Lee et al. [36] did show that IMRT had improved LR recurrence-free survival at 2 years over conventional RT techniques ( $52 \%$ vs. $20 \%$ ) but did not significantly improve OS rates. In general, for patients receiving IMRT (with or without salvage 
surgery), LR control and OS rates at 2 years ranged from $27-77 \%$ and $19.5-58 \%$, respectively $[35,45]$.

Similarly, to some brachytherapy studies, patients receiving reirradiation (either using conventional or newer RT techniques) with salvage surgery had improved outcomes. One phase III randomized trial by Janot et al. [46] divided patients into receiving salvage surgery alone or with adjuvant full-dose reirradiation with chemotherapy. Patients in the radiation arm (using conventional RT) had significantly improved LR control and DFS rates but no significant change in OS rates at 2 years [46]. Likewise, a study by Takiar et al. [47] showed improved disease control and survival outcomes using adjuvant IMRT after surgery (vs. surgery alone) in HNSCC patients with a 5 -year OS rate of $57 \%$.

Complications appear less frequent or severe compared to EBRT techniques including IMRT. In some brachytherapy studies, complication rates ranged as high as $50-60 \%$ for acute grade 1-2 toxicities including mucositis, dermatitis, hoarseness, infection, or hematoma $[12,14,17,26,27]$. Late grade $3-4$ toxicities included complications like fistula, soft tissue necrosis, ORN, dysphagia, fibrosis, trismus, severe hemorrhage, and wound dehiscence, with rates ranging from $7-51 \%[9,10,12,17$, $18,20,21,28,29,37,40,42]$. In the study by Takiar et al. [47] using IMRT for re-irradiation, there was a 5-year grade $\geq 3$ toxicity rate of $48 \%$, with three patients dying due to radiation toxicity. However, the majority of patients who now are receiving their first round of radiation with IMRT may likely have fewer overall complications, if or when they receive reirradiation. Literature is limited at this time to support this theory but will likely be shown in coming years.
We propose an algorithm to help guide treatment options for patients with RHNC (Figure 2). For example, for patients with resectable locoregional recurrence, consider surgical resection followed by brachytherapy or EBRT with or without chemotherapy or immunotherapy. Using brachytherapy versus external radiation techniques like IMRT may depend on the timing, type of previous RT, and location of recurrence. Despite the safety, ease of use, and promising efficacy advantages of ${ }^{131} \mathrm{Cs}$, the use for specific RHNC populations requires further investigation. Unfortunately, the majority of published literature is retrospective, and the patient cohorts and treatment approaches used are very heterogeneous. In theory, combining a radiation boost to salvage surgery may provide dual therapy with less radiotherapy toxicity. ${ }^{131} \mathrm{Cs}$ with salvage surgery and other combinations with immunotherapy may offer a viable treatment pathway for RHNC for some patients and should be studied in future clinical trials. Our institution has recently been studying ${ }^{131} \mathrm{Cs}$ brachytherapy in RHNC with preliminary promising results. At this time, HDR and PDR appear to be the current techniques of choice due to optimization of implant dosimetry and geometric sparing with and reduced treatment time.

\section{Conclusions}

Treatment options for RHNC remain challenging. Although brachytherapy alone can be used to treat RHNC, locoregional control rates and overall survival rates are higher when brachytherapy is used as adjunctive therapy to salvage surgery. These rates remain comparable or improved when brachytherapy is utilized in

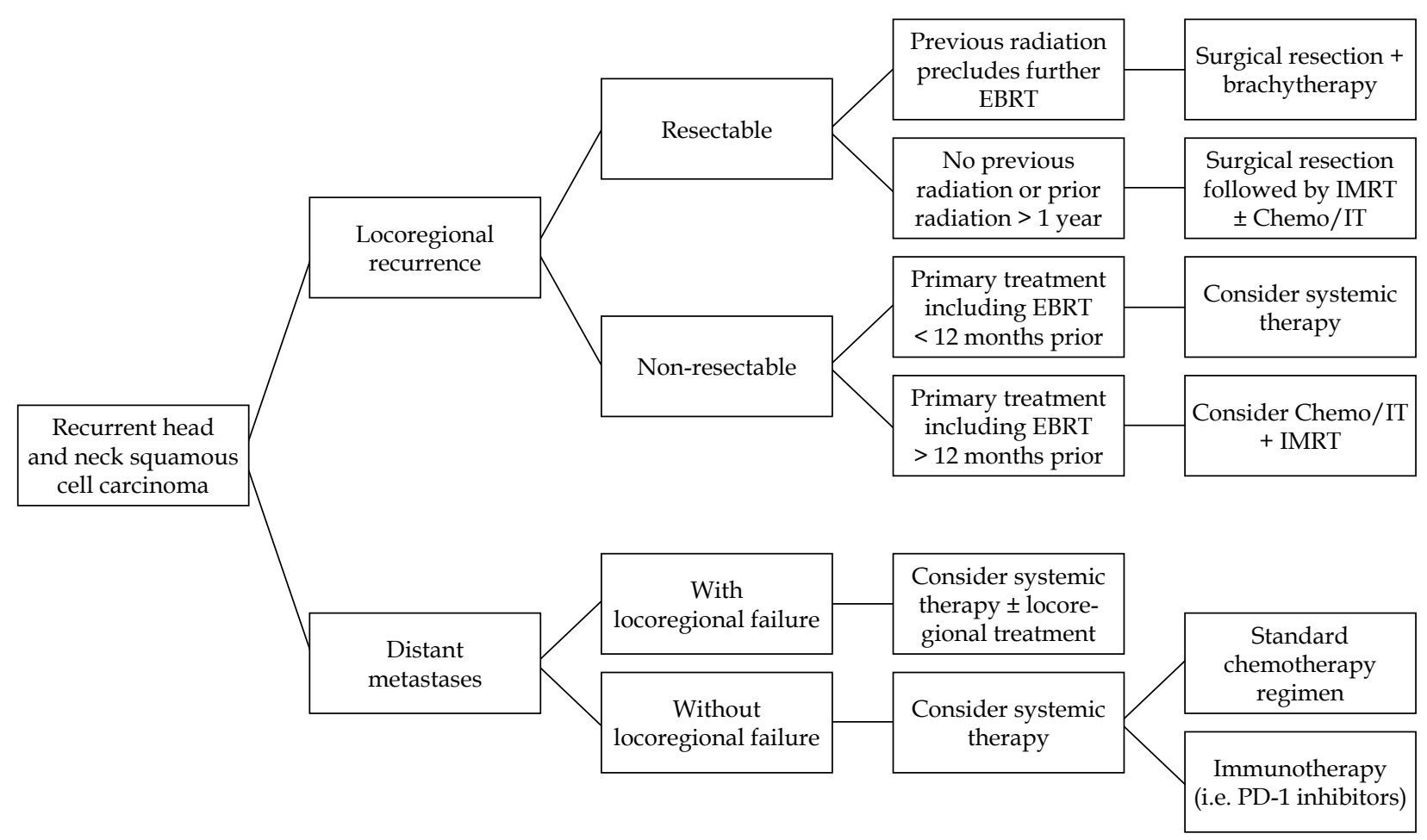

Fig. 2. Proposed algorithm for treating recurrent head and neck squamous cell carcinoma 
neck disease with or without surgery. Regardless of the type of radiotherapy used, these patients continue to face significant risks for recurrence and complications including fistula formation, carotid rupture, dysphagia, osteoradionecrosis, and prolonged hospital stay $[9,10,20,21,42,48,49,50]$. With the recent introduction of isotopes with more favorable properties, complication rates have the potential to be lower while preserving local regional control rates.

\section{Disclosure}

Authors report no conflict of interest.

\section{References}

1. Siegel R, Miller K, Jemal A. Cancer statistics. CA Cancer J Clin 2016; 66: 7-30.

2. Siegel R, Miller K, Jemal A. Cancer statistics. CA Cancer J Clin 2017; 67: 7-30.

3. Siegel R, Miller K, Jemal A. Cancer statistics. CA Cancer I Clin 2015; 65: 5-29.

4. Vokes E, Weichselbaum R, Lippman S, Hong WK. Head and neck cancer. N Engl J Med 1993; 328: 184-194.

5. Grimard L, Esche B, Lamothe A et al. Interstitial low-doserate brachytherapy in the treatment of recurrent head and neck malignancies. Head Neck 2006; 28: 888-895.

6. Henderson P, Kutler D, Parashar B et al. Neither high-dose nor low-dose brachytherapy increases flap morbidity in salvage treatment of recurrent head and neck cancer. J Contemp Brachytherapy 2016; 8: 308-312.

7. Quon H, Harrison LB. Brachytherapy in the treatment of head and neck cancer. Oncology (Williston Park) 2002; 16: 1379-1396.

8. Strnad V, Lotter M, Kreppner S, Fietkau R. Reirradiation for recurrent head and neck cancer with salvage interstitial pulsed-dose-rate brachytherapy: Long-term results. Strahlenther Onkol 2015; 191: 495-500.

9. Narayana A, Cohen G, Zaider M et al. High-dose-rate interstitial brachytherapy in recurrent and previously irradiated head and neck cancers-preliminary results. Brachytherapy 2007; 6: 157-163.

10. Martinez-Fernandez M, Alcalde J, Cambeiro M et al. Perioperative high dose rate brachytherapy (PHDRB) in previously irradiated head and neck cancer: Results of a phase I/II reirradiation study. Radiother Oncol 2017; 122: 255-259.

11. Schiefke F, Hildebrandt G, Pohlmann S et al. Combination of surgical resection and HDR-brachytherapy in patients with recurrent or advanced head and neck carcinomas. I Craniomaxillofac Surg 2008; 36: 285-292.

12. Strnad V, Lotter M, Kreppner S, Fietkau R. Re-irradiation with interstitial pulsed-dose-rate brachytherapy for unresectable recurrent head and neck carcinoma. Brachytherapy 2014; 13: 187-195.

13. Scala L, Hu K, Urken M et al. Intraoperative high-dose-rate radiotherapy in the management of locoregionally recurrent head and neck cancer. Head Neck 2013; 35: 485-492.

14. Teudt I, Kovacs G, Ritter M et al. Intensity modulated perioperative HDR brachytherapy for recurrent and/or advanced head and neck metastases. Eur Arch Otorhinolaryngol 2016; 273: 2707-2715.

15. Kasperts N, Slotman B, Leemans C et al. A review on re-irradiation for recurrent and second primary head and neck cancer. Oral Oncol 2005; 41: 225-243.

16. Patel P, Salama J. Reirradiation for recurrent head and neck cancer. Expert Rev Anticancer Ther 2012; 12: 1177-1189.
17. Puthawala A, Nisar Syed A, Gamie S et al. Interstitial lowdose-rate brachytherapy as a salvage treatment for recurrent head-and-neck cancers: long-term results. Int J Radiat Oncol Biol Phys 2001; 51: 354-362.

18. Hepel J, Nisar Syed A, Puthawala A et al. Salvage high-doserate (HDR) brachytherapy for recurrent head-and-neck cancer. Int I Radiat Oncol Biol Phys 2005; 62: 1444-1450.

19. Jiang $P$, Jiang $Y$, Wang J et al. Percutaneous ultrasonography-guided permanent iodine-125 implantation as salvage therapy for recurrent head and neck carcinomas. Cancer Biother Radiopharm 2011; 26: 753-757.

20. Rudzianskas V, Inciura A, Juozaityte E et al. Reirradiation of recurrent head and neck cancer using high-dose-rate brachytherapy. Acta Otorhinolaryngol Ital 2012; 32: 297-303.

21. Park R, Liberman F, Lee DJ et al. Iodine- 125 seed implantation as an adjunct to surgery in advanced recurrent squamous cell cancer of the head and neck. Laryngoscope 1991; 101: 405-410.

22. Pellizzon A, dos Santos Novaes P, Conte Maia M et al. Interstitial high-dose-rate brachytherapy combined with cervical dissection on head and neck cancer. Head Neck 2005; 27: 1035-1041.

23. Pham A, Arora S, Wernicke G et al. Cesium-131 brachytherapy in high risk and recurrent head and neck cancers: first report of long-term outcomes. J Contemp Brachytherapy 2015; 7: 445-452.

24. Kupferman M, Morrison W, Santillan A et al. The role of interstitial brachytherapy with salvage surgery for the management of recurrent head and neck cancers. Cancer 2007; 109: 2052-2057.

25. Wong S, Machtay M, Li Y. Locally recurrent, previously irradiated head and neck cancer: concurrent re-irradiation and chemotherapy, or chemotherapy alone? J Clin Oncol 2006; 24: 2653-2658.

26. Bartochowska A, Skowronek J, Wierzbicka $\mathrm{M}$ et al. Is there a place for brachytherapy in the salvage treatment of cervical lymph node metastases of head and neck cancers? Brachytherapy $2015 ; 14:$ 933-938.

27. Huang $\mathrm{H}, \mathrm{Xu} \mathrm{S}, \mathrm{Li} F$ et al. Clinical application of computed tomography-guided ${ }^{125}$ I seed interstitial implantation for head and neck cancer patients with unmanageable cervical lymph node metastases. Eur J Med Res 2016; 21: 18.

28. Tselis N, Ratka M, Vogt HG et al. Hypofractionated accelerated CT-guided interstitial ${ }^{192}$ Ir-HDR-brachytherapy as re-irradiation in inoperable recurrent cervical lymphadenopathy from head and neck cancer. Radiother Oncol 2011; 98: 57-62.

29. Nutting C, Horlock N, A'Hern R et al. Manually after-loaded ${ }^{192}$ Ir low-dose rate brachytherapy after subtotal excision and flap reconstruction of recurrent cervical lymphadenopathy from head and neck cancer. Radiother Oncol 2006; 80: 39-42.

30. Cox J, Stetz J, Pajak TF. Toxicity criteria of the Radiation Therapy Oncology Group (RTOG) and the European Organization for Research and Treatment of Cancer (EORTC). Int J Radiat Oncol Biol Phys 1995; 31: 1341-1346.

31. Parasher B, Wernicke A, Pavese A et al. Cesium-131 permanent brachytherapy: dosimetric evaluation and radiation exposure to surgeons, radiation oncologists, and staff. Brachytherapy 2011; 10: 508-513.

32. Zhu L, Jiang $\mathrm{Y}$, Wang $\mathrm{J}$ et al. An investigation of ${ }^{125} \mathrm{I}$ seed permanent implantation for recurrent carcinoma in the head and neck after surgery and external beam radiotherapy. World J Surg Oncol 2013; 11: 60.

33. Yondorf M, Schwartz T, Boockvar J et al. Radiation exposure and safety precautions following ${ }^{131} \mathrm{Cs}$ brachytherapy in patients with brain tumors. Health Phys 2017; 112: 403-408.

34. Goodwin WJ Jr. Salvage surgery for patients with recurrent squamous cell carcinoma of the upper aerodigestive tract: when do the ends justify the means? Laryngoscope 2000; 110: $1-18$. 
35. Strojan P, Corry J, Eisbruch A et al. Recurrent and second primary squamous cell carcinoma of the head and neck: when and how to irradiate. Head Neck 2015; 37: 134-150.

36. Lee N, Chan K, Bekelman J et al. Salvage re-irradiation for recurrent head and neck cancer. Int J Radiat Oncol Biol Phys 2007; 68: 731-740.

37. Glatzel M, Buntzel J, Schroder D et al. High-dose-rate brachytherapy in the treatment of recurrent and residual head and neck cancer. Laryngoscope 2002; 112: 1366-1371.

38. Meng N, Liang Jiang Y, Jie Wang J et al. Permanent implantation of iodine- 125 seeds as a salvage therapy for recurrent head and neck carcinoma after radiotherapy. Cancer Invest 2012; 30: 236-242.

39. Wiegand S, Sesterhenn AM, Zimmermann AP et al. Interstitial HDR brachytherapy for advanced recurrent squamous cell carcinoma of the head and neck. Anticancer Res 2013; 33: 249-252.

40. Cornes P, Cox H, Rhys-Evans P et al. Salvage treatment for inoperable neck nodes in head and neck cancer using combined iridium-192 brachytherapy and surgical reconstruction. Br J Surg 1996; 83: 1620-1622.

41. Teckie S, Scala L, Ho F et al. High-dose-rate intraoperative brachytherapy and radical surgical resection in the management of recurrent head-and-neck cancer. Brachytherapy 2013; 12: 228-234.

42. Perry D, Chan K, Wolden S et al. High-dose-rate intraoperative radiation therapy for recurrent head-and-neck cancer. Int J Radiat Oncol Biol Phys 2010; 76: 1140-1146.

43. Kolotas C, Tselis N, Sommerlad M et al. Reirradiation for recurrent neck metastases of head-and-neck tumors using CT-guided interstitial ${ }^{192}$ Ir HDR brachytherapy. Strahlenther Onkol 2007; 183: 69-75.

44. Bollet M, Lapeyre M, Marchal C et al. Cervical lymph node relapses of head-and-neck squamous cell carcinoma: is brachytherapy a therapeutic option? Int J Radiat Oncol Biol Phys 2001; 51: 1305-1312.

45. Sulman E, Schwartz D, Le T et al. IMRT reirradiation of head and neck cancer-disease control and morbidity outcomes. Int J Radiat Oncol Biol Phys 2009; 73: 399-409.

46. Janot F, de Raucourt D, Benhamou E et al. Randomized trial of postoperative reirradiation combined with chemotherapy after salvage surgery compared with salvage surgery alone in head and neck carcinoma. J Clin Oncol 2008; 26: 5518-5523.

47. Takiar V, Garden A, Ma D et al. Reirradiation of head and neck cancers with intensity modulated radiation therapy: outcomes and analyses. Int J Radiat Oncol Biol Phys 2016; 95: 1117-1131.

48. Vermorken JB, Specenier P. Optimal treatment for recurrent/ metastatic head and neck cancer. Ann Oncol 2010; 21: 252-261.

49. Jeong S, Yoo EJ, Kim JY et al. Re-irradiation of unresectable recurrent head and neck cancer: Helical tomotherapy as image-guided intensity-modulated radiotherapy. Rad Oncol J 2013; 31: 206-215.

50. Vargo J, Kubicek G, Ferris R et al. Adjuvant stereotactic body radiotherapy + cetuximab following salvage surgery in previously irradiated head and neck cancer. Laryngoscope 2014; 124: 1579-1584. 